\title{
ガス被包アーク溶接用送給ガスの乾燥器についで
}

\author{
関口春次郎** 益本功**

\section{Desiccator of Supplied Gas for Gas-Shielded Metal Arc Welding*}

By Haruziro Sekiguchi** and Isao Masumoto**

\begin{abstract}
It is necessary to use a supplied gas having humidity as low as possible for gas-shielded metal arc welding. But it is not always easy to get everywhere the recommended gas for welding, i.e. super-pure and super-dried gas charged into a specially treated cylinder.

The authors carried out experiments about drying of gas supplied from a cylinder with some desiccants : sodium alumino silicate, activated alumina and silica gel. The dew point of the gas flowing out through a desiccator was continuously measured until the given amount of a desiccant broke. Carbon dioxide was used for the supplied gas.

The results are as follows :

1) Sodum alumino silicate has a drying capacity larger than activated alumina and silica gel. The sodium alumino silicate of $640 \mathrm{~g}$ warrants a supply of $\mathrm{CO}_{2}$ gas under $-25^{\circ} \mathrm{C}$ dew point for 112 hrs., i.e. 7 cylinders. The dew point of gas through the desiccant is under $-40^{\circ} \mathrm{C}$ from the first cylinder to fifth.

2) Activated alumina and silica gel warrant a supply of only two cylinders of $\mathrm{CO}_{2}$ gas under $-20^{\circ} \mathrm{C}$ dew point through each desiccant.

3) An experimental formula was established for the relation between charged weight of sodium alumino silicate and break-time.
\end{abstract}

\section{1. 緒言}

ガス被包金属アーク溶接においては，溶着金属の水素 含量に送給ガスの湿度が影響するから，送給ガスの水分 含量はできるだけ少ないととが望ましい，てのためには

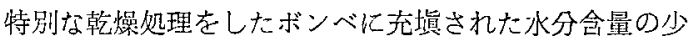
ない，いわゆる超乾燥ガスを用いるか，ボンべから溶接 頭认送給される途中でガスを乾燥するかの力法がある. 後者の乾澡剂として活性アルミナおよびシリカゲルを用 いれば，实験室的な条件（理想的な活性状態乙導管に水 分を含まない場合)では，送給ガスの露点をかなり低下 できる1).

しかしながら実際の溶接条件で一つの乾燥器がどれだ けのガスを，要求される水分含量以下まで下げられる か，すなわち破過時間についてはいまだ明らかにされて いない，換言す狄ばボンべから送給されるガスは，一般 の化学工業で脱水処理されるガスあるいは大気に比較し て，加り低い湿度を有している，しかし溶接の目的 に，との送給ガスをさらに脱水して使用したい場合，と のような低い湿度の筙围におけるガスの吸着脱水の実験

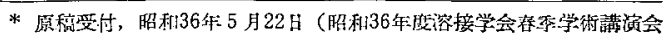
比( 打発表)

** 正員, 名古堅大阪工学部 Member, Faculty of Engineering, Nagoya University
は少なく，㷋来の文献の各乾燥剂に対する諸数值を基礎 にして乾嬠器を設計することができない.

そこで著者らは，種々の吸着剂について，ボンベから 一定流量でガスを送給乾燥する場合，破過時間と乾燥器 の大きさ(吸着剤の量)との関係を明らかにするために 実験および考察を行なった。

\section{2. 実 験 方 法}

一定容量の乾燥器の完畦吸着剂を種々変えて，あらか じめ $1 l$ の水在泩入したボンベに充填された液体炭酸(

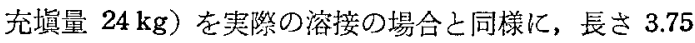
m のゴム導管を通じ流量 $30 \mathrm{cfh}$ で連続に送給し，乾燥 器出口の炭酸ガスの露点を光電管式露点湿度計で連続測 定し，乾燥器の破過㭙間和よび破過するまでに乾燥しう るボンベの本数を求めた．乾燥器の中には直径約 $60 \mathrm{~mm}$ 長さ約 $240 \mathrm{~mm}$ のステンレス鋼製円筒があり，との简 内に吸着剂約 450 640g が充兴ざれ，送給ガスはこの 円筒を通過するよう汅した。

吸着剂としては結晶ゼオライト (Linde Molecular Sieves 4A), 活性アルミナおよびシリカゲルを用いた。 Molecular Sieves は Fig. 1 および Fig. 22) に示すご 上く特に湿度の低いガスの乾燥に效果があり，化学組成 は一般式しして $\mathrm{Me} x / n\left[\left(\mathrm{AlO}_{2}\right)_{\mathrm{x}}\left(\mathrm{SiO}_{2}\right)_{\mathrm{y}}\right] \cdot m \mathrm{H}_{2} \mathrm{O}$ で表 


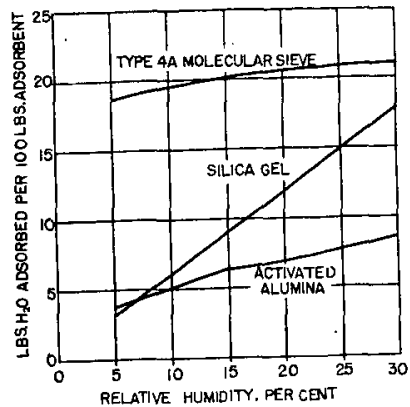

Fig. 1 Water vapor adsorption capacity of various desiccants, at $25^{\circ} \mathrm{C}^{2}$ )

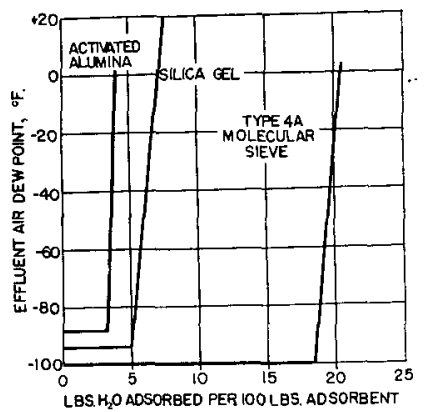

Fig. 2 Dynamic air drying data of various desiccants ${ }^{2}$ )

わされる. $(x / n)$ は原子価 $n$ の置換できる陽イオンの 数, $m$ は結壯水分子の数で, この結晶水 $m \mathrm{H}_{2} \mathrm{O}$ の脱離 により Molecular Sieves としての優れた性質を有する ととになる。 との Molecular Sieve は分子構造および 吸着のメカニズムから一㮔の包接化合物亡考えられる。 琴在，市販されている A 型合成ぜオライトの实験式は $\mathrm{Me} 12 / n\left[\left(\mathrm{AlO}_{2}\right)_{12}\left(\mathrm{SiO}_{2}\right)_{12}\right] 27 \sim 30 \mathrm{H}_{2} \mathrm{O}$ 亿相当する. 木

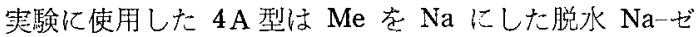
オライトであり粒状（14 30 mesh）である.

なお実験室の温度は $15 \sim 20^{\circ} \mathrm{C}$ の範园で一定に保ち， ボンベから一定流量 $30 \mathrm{cfh}$ でガスを流出した。流量計 付調整器 Regulator-Flowmeter は凍結しない程度に $500 \mathrm{~W}$ 電球で時々加温した。

\section{3. 実 験 結 果}

雪験結果を Fig. 3,4 および5 亿示す.Fig. 3 は結奛 ゼオライト (sodium alumino silicate), Fig. 4 牥活性 アルミナ, Fig. 5 はシリカゲルの埸合である.

○の太実線は乾燥器出口ガスの蕗点を示し，○および 細点線は乾燥器を経ないで送給された場合，换言すれば 乾㯒器入口の炭酸ガスの露点を示す. 図中のローマ数 字は，吸着剤を含む乾燥器を通してガスを供給したボン ベの本数を示す. Fig. 3 の結盟ゼオライトの場合好 3 本

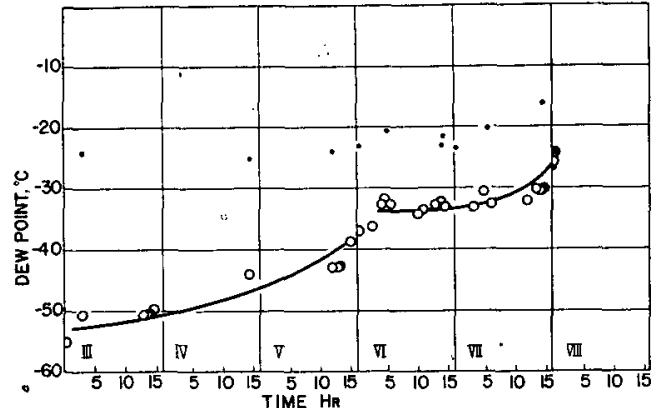

Fig. 3 Dew point of carbon dioxide gas flowing through desiccator containing sodium alumino silicate (Linde molecular sieves $4 \mathrm{~A}$ ) and gas flowing time

Remarks : - $\bigcirc$ through desiccant

no desiccant

III, IV, V $\cdots$ No. of cylinder

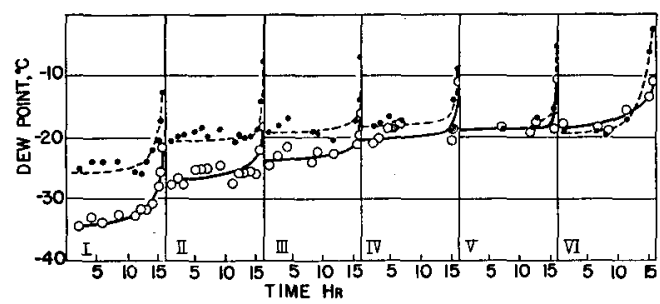

Fig. 4 Dew point of carbon dioxide gas flowing through desiccator containing activated alumina and gas flowing time

Remarks : - $\bigcirc$ through desiccant

* no desiccant I ,II, III,IV .. No. of cylinder

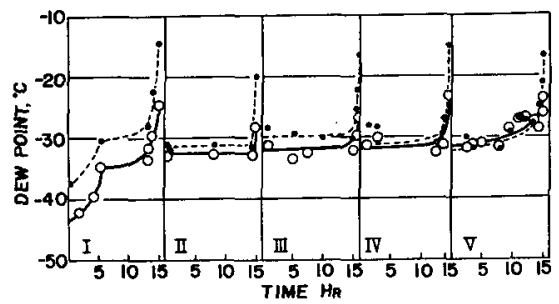

Fig. 5 Dew point of carbon dioxide gas flowing through desiccator containing silica gel and gas flowing time

Remarks : - $\bigcirc$ through desiccant

- no desiccant I , II, III, IV No. of cylinder

目からが記録してある。すなわち最初の 2 本は 3 本目と 同程度の䩖燥がスが得ら机，ボンべが完全に空になるま で, 茈燥器出ロガスの露点は $-50^{\circ} \mathrm{C}$ 以下を示した。そ して乾燥器の処理本数の增加々と屯に出ロガスの露点は しだいに增加し，8本目の最初では乾燥器を通した場合 
あ通さない場合も差がなく，-25ㄷ であった。しかし， この場合は Fig. 4 および 5 の活性アルミナおよびシリ カゲルの場合のどとく，ボンべの残留左の减少すなわち 1 本のボンベでの好理時間の経過につれ，特に低灰時に あらわれている露点の異常上鼠は，7本目でもまだあ らわれていない.したがってボンべから供給される溶接 用送給ガスの乾燥の目的をボンべ残留圧の低正時の露点 上显防止だけに限るならば，すなわちFig.3 において露 点 $-25^{\circ} \mathrm{C}$ 程度の炭酸ガスを得ることを目的とするなら ば，結昆ゼオライト乾燥器はボンベ 8 本り上を処理しう るあのと思わ机るが，本実験では 8 本目で一応結晶ゼオ ライトは破過したもの上考え，実驗を中止した。

Fig. 4 の活性アルミナの場合は睤に一本目から，乾燥 器を通さない場合のボンベ残留圧の低圧時におりる流出 ガスの露点の翼常上昇に対応して，乾燥ガスの露点も姏 理時間が10時間を過ぎると急激に上抟している。てして このサイクルが各ボンベで繰返されボンベの処理本数の 增加々ともに漧燥器出口ガスの最低露点（各ボンぶ処理

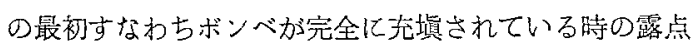
）はしだいに上昇し，処理本数 5 本で完全に破過してい る.したがってとの場合は，活性アルミナ充䁲層が完全 に破過するまでに5本のガスが処理しうるわけである が, 上述のでとく, 既に 1 本目から低压時の露点異常上 䒜老防止する能力はない. したがって露点 $-15^{\circ} \mathrm{C}$ 以上 の炭酸ガスが溶接用として送給されるととを警哉すると すれば4処理本数は 3 本，流出時間47時間で充唒層を再 活性化しなければならない，送給ガスの露点として $-20^{\circ} \mathrm{C}$ 以下を要求すれば，処理本数は 2 本となる.

Fig. 5 のシリカゲルの場合は, 活性アルミナの場合と ほぼ同様の傾向を示し，完全な破過は 4〜5本目である が，溶接用送給ガスの乾燥割としては，乙の程度の旮塻 層ではせいぜいボンベ 1 本の乾燥能力しかないことがわ 加る.

\section{4. 考察}

(i) Fig. 3,4 および 5 の害験綕果の相違は，Fig. 1 および Fig. 2 に示した各吸着斉の低湿度における吸着 平衡を比較すれば，ある程度理解されるところである。 すなわち相刘湿度 $5 \%$ における吸着容量（at $25^{\circ} \mathrm{C）を}$ 比較すれば，Fig. 1 からわかるように，

Linde 4A Molecular Sieves …約 $18 \mathrm{~g} \cdot \mathrm{H}_{2} \mathrm{O} / 100 \mathrm{~g}$

\begin{tabular}{|c|c|}
\hline 活性アルミナ & ‥約 4 \\
\hline リカゲル & …約 3 \\
\hline
\end{tabular}

である。

また既報の著者らの奏験において，㽞性アルミナおよ
びシリカゲルの理想的な吸着状況（再活性化值後で導管 はガラス管）ては，乾燥器出口ガスの湿度をかなり低下 できたが，本些験の結果，この上うな低湿度のガスはき わぬて限られた条件以外は得難く，実際の溶接条件では これらの吸着剂を使用した場合は，かなり大きな乾燥器 が必琶になるとしが予想される。

以下本奏験条件に招ける各吸着剂の破過時間を理論的 に求め，実験結果と比較してみよう。

(ii) 活性アルミナの場合

一定温度におりる吸着剂の平衡吸禇量亡送給がスの湿 度との関係曲線, すなわち吸着平衡の等温線が直線の場 合につき, 河添Eは破過時間を求める近似式として次式 を提示している5).

$$
\theta_{d}=\frac{\beta \gamma}{U} H\left(1-\sqrt{\frac{\pi U}{K_{\alpha} H}}\right)
$$

$こ こ た$

$\theta_{d}:$ 破過時間 $\mathrm{hr}$

$\beta: q_{0} / c_{0} \quad c_{0}$ 亿対する吸着係数 $\left(\mathrm{m}^{3} / \mathrm{kg}\right.$ ・吸着剂 $)$

$\gamma:$ 充填密度 $\left(\mathrm{kg} / \mathrm{m}^{3}\right)$

$U$ : 乾燥器内を空にした場合の器内の流速, superficial linear velocity $(\mathrm{m} / \mathrm{hr})$

$H:$ 乾燥器の高さ (m)

$K_{\alpha}$ : 濃度差に基く総括容望係数 $(1 / \mathrm{hr})$

$c_{0}:$ 入灙度 $\left(\mathrm{kg} / \mathrm{m}^{3}\right)$

$q_{0}: c_{0}$ 亿平衡な吸着率 $(\mathrm{kg} / \mathrm{kg}$ 吸着郕)

ボンベから送給されるガスの水分含量は乾暞器の入口 に利て一定でなく，ボンベの残留圧の減少とともに增

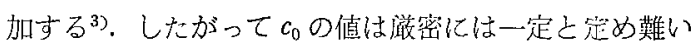
がここではボンベから送給された全ガス中に含まれる水 分会量の平均值を $c_{0}$ とした。

すなわち、いまボンべの液体炭酸充㘿量を $24 \mathrm{~kg}$, ボ ンベの温度を $20^{\circ} \mathrm{C}$ とれば，放出されるる炭酸ガスの全 签量は，送給ガス压を $1.5 \mathrm{~atm}$ として次式で求められ 万.

炭酸ガスの全体積 $\left(V_{t}\right)=22.4 \times \frac{24000}{44} \times \frac{273+20}{273} \times$

$$
\frac{1}{1.5}=8742 l
$$

このガスの中に含まれる全水分量 $H_{t}$ すなわち限界水分 竡は次式で求められる゙.

$$
\begin{aligned}
& H_{i}=H_{g l}+H_{g} \\
& H_{g l}=D_{g l} \times V_{f g l} \times 10^{-3} \\
& H_{g}=P_{\mathrm{H}_{2} \mathrm{O}} \times 0.80357 \times \frac{273 v}{273+T}\left(1+\frac{1}{\log e}\right. \\
& \left.\left(\log P_{i}-\log P_{f}\right)\right]
\end{aligned}
$$

ここて

$H_{t}$ : 液化炭酸ボンベから送給される炭酸ガスの全 水分含量, $\mathrm{g}$ 
$H_{g l}$ :ボンべに液相と気相とが共存する状態で送給 される炭酸ガスの水分含量, $\mathrm{g}$

$H_{g}$ :ボンべ内が気相のみとなって送給される炭酸 ガスの水分含量, $\mathrm{g}$

$D_{g l}$ : ボンベ内に液相と気相之が共存する状態で送 給される炭酸ガスの絶対湿度, $\mathrm{g} / \mathrm{m}^{3}$

$V_{f B l}$ : ボンベ内に液相と気相とが共存する状態で 送給される炭酸ガスの総体積, $l$

$P_{\mathrm{H}_{2} \mathrm{O}}$ : ボンベ内の水蒸気分王, $\mathrm{atm}$

$P_{i}:$ ボンベの最初の充填压, atm

$P_{f}:$ 流出压, atm

$v:$ ボンベの内容積, $l$

$T:$ 温度, ${ }^{\circ} \mathrm{C}$

$$
\begin{aligned}
& D_{g t}=\frac{0.02307}{56.495} \times \frac{18}{22.4} \times 1.5 \frac{273}{273+20} \\
& \times 10^{3}\left(\mathrm{~g} / \mathrm{m}^{3}\right) \\
& V_{f g l}=8742-40 \times 5.6495(l) \\
& P_{\mathrm{H}_{2} \mathrm{O}}=0.02307 \mathrm{~atm} \text {. } \\
& P_{i}=56.495 \mathrm{~atm} . \\
& P_{f}=1.5 \mathrm{~atm} \text {. } \\
& v=40 l \\
& T=20^{\circ} \mathrm{C} \\
& H_{\xi}=2.97+3.20=6.17\left(\mathrm{~g} / \mathrm{m}^{3}\right)
\end{aligned}
$$

したがって

$$
c_{0}=\frac{H_{t}}{V_{t}}=\frac{6.17}{8.742}=0.71 \mathrm{~g} / \mathrm{m}^{3}\left(\text { 露点 }-25^{\circ} \mathrm{C}\right) \cdots
$$

$q_{0}$ については本䒠験のでとく低湿度の Isotherm（等 温平衡）のデーターがないので精確な值は定め難いが， 供試活性了ルミナに関する $c_{0}=20 \sim 1 \mathrm{~g} / \mathrm{m}^{3}$ 亿打汀召䛧 を外插して $c_{0}=0.71 \mathrm{~g} / \mathrm{m}^{3}$ 亿おいて $q_{0}=0.055$ とした6).

総括容量係数 $K_{a}$ は住友活性アルミナのカタログの値 $2001 / \mathrm{min}=1200 \mathrm{1} / \mathrm{hr}$ を採用した。同じく充填密度〉 もカタログの值 $800 \mathrm{~kg} / \mathrm{m}^{3}$ を用いだ).

その他（1）式におけるUおよび $H$ の值を，実験 条件から整理すれば Table 1 のと枋りである.

てれらの值を用いて，活性アルミナの場合の破過時間 を求め,

活性アルミナ : $\theta_{d}=18.8 \mathrm{hrs}$ が得られた。

（iii）シリカゲルの場合

ての場合屯（1）式が適用できると仮定して計算を行 なった. $c_{0}=0.71 \mathrm{~g} / \mathrm{m}^{3}$ (露点 $-25^{\circ} \mathrm{C}$ ) $q_{0}=0.03$ とし， また総括容量係数 $K_{a}$ は次式》から求めた。

$$
\frac{1}{K_{x}}=\frac{1}{K_{H t} a_{v}}=\frac{1}{k_{f t} a_{\nu}}+\frac{1}{\beta k_{S} a_{v}} .
$$

ただし， $K_{H} a_{v}=(2400) G^{0.55}$
$K_{t I}$ : 湿度差传基つく総括物質移動係数 $\left[\mathrm{kg} \cdot \mathrm{H}_{2} \mathrm{O} /\right.$ $\left.\mathrm{hr} \cdot \mathrm{m}^{2} \cdot \Delta h\right]$

$a_{v}$ : 乾燥器単位容積内の乾燥剂の有效表西積 $\left[\mathrm{m}^{2} /\right.$ $\mathrm{m}^{3}$ 充境層]

$k_{H}$ : 湿度差に基づくガス境膜物質移動係数 $\left[\mathrm{kg} \cdot \mathrm{H}_{2}\right.$ $\left.\mathrm{O} / \mathrm{hr} \cdot \mathrm{m}^{2} \cdot \Delta x\right]$

$k_{S}:$ 固体境膜物質移政係数 $\left[\mathrm{kg} \cdot \mathrm{H}_{2} \mathrm{O} / \mathrm{hr} \cdot \mathrm{m}^{2} \cdot \Delta x\right]$

$\Delta h:$ 湿度差

$\Delta x:$ 吸着量の差

$G:$ ガスの質量速度 $\left[\mathrm{kg} \cdot\right.$ 乾燥ガス $\left./ \mathrm{hr} \cdot \mathrm{m}^{2}\right]$

$$
G=\rho U
$$

$\rho:$ ガスの密度 $\mathrm{kg} / \mathrm{m}^{3}$

$a_{v}=1470 \mathrm{~m}^{2} / \mathrm{m}^{3}$ 扰よび $k_{S}=4.70 \mathrm{~kg} \cdot \mathrm{H}_{2} \mathrm{O} / \mathrm{hr} \cdot \mathrm{m}^{2} \cdot \Delta x$ をそれぞれ文献の值7から代入して計算すれば

$$
\begin{aligned}
& k_{H} a_{v}=2400 \times 542^{0.55}=7.7 \times 10^{4} \\
& \beta k_{S} a_{v}=42.25 \times 4.7 \times 1470=291928
\end{aligned}
$$$$
\therefore \quad K_{\alpha}=K_{H} a_{v}=60653
$$

シリカゲルの充䇠密度 $\gamma$ は文献の值8? の平均值をとり $\gamma=695 \mathrm{~kg} / \mathrm{mm}^{3}$ とする.

これらの値および Table 1 の值から（1）式を諳算す れば

シリカゲル : $\theta_{d}=19.6 \mathrm{hrs}$

(iv) Molecular Sieves $4 \mathrm{~A}$ の場合

Molecular Sieves 4A については総括容量係数 $K_{\alpha} の$ 計算に必要な諸数值が明らかでないので unused bed の 概念9”加ら破過時間を求めた，乙の点について説明する と，吸着は比較的せまい图内（Absorption zone）でお こり,ての Absorption zone は Fig. 6 のごとく潮次移 動する． $c_{0} / 2$ 濃度を示す点は $U / \beta \gamma$ なる速度で移動す るから ${ }^{8}$, 入口加ら $x$ の距離化むる点の濃度が $c_{0} / 2$ に 達するに要する特間は $x / \frac{U}{\beta \gamma}$ でする。

いま吸着帯の巾を $z[\mathrm{~m}]$ とする、吸着带の吸着㫪分
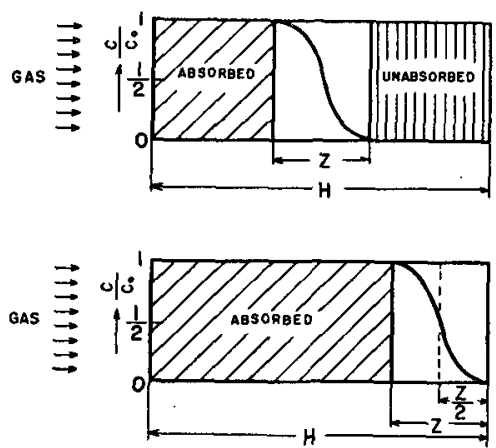

Fig. 6 Transfer of absorption length and length of unused bed

$H$ : length of dessicant

$Z$ : transfer zone length or absorption zone

$Z / 2:$ length of unused bed 
Table 1 Condition of experiment

\begin{tabular}{c|c|c|c|c|c}
\hline Desiccant & $\begin{array}{c}\text { Diameter of } \\
\text { desiccator, } \\
D, m\end{array}$ & $\begin{array}{c}\text { Height of } \\
\text { desiccator, } \\
H, m\end{array}$ & $\begin{array}{c}\text { Weight of } \\
\text { charged } \\
\text { desiccant, } \\
M, \mathrm{~kg}\end{array}$ & $\begin{array}{c}\text { Flow rate of } \\
\text { inlet gas, } \\
V, \mathrm{~m}^{3} / \mathrm{hr}\end{array}$ & $\begin{array}{c}\text { Superficial } \\
\text { linear velocity, } \\
\text { U, } \mathrm{m} / \mathrm{hr}\end{array}$ \\
\hline Activated alumina & 0.056 & 0.245 & 0.50 & 0.804 & 326 \\
Silica gel & 0.061 & 0.242 & 0.45 & 0.804 & 275 \\
Molecular sieves 4A & 0.063 & 0.245 & 0.64 & 0.804 & 262 \\
\hline
\end{tabular}

布は $c / c_{0}=q / q_{0}=1 / 2$ において大体対称であるから，吸 着帯はなお吸着しうる能力を平均的に半分有し， $(z / 2)$ が吸着にあずからない，ての $z / 2$ を length of unused bed, 吸着寡の長さ $z$ を transfer zone length という. すな和ち $(H-z / 2)$ 点の濃度が $c_{0} / 2$ になるときを破過 と考える上

$$
\theta_{d}=\frac{(H-z / 2)}{\left(\frac{U}{\beta \gamma}\right)}=\frac{\beta \gamma}{U}\left(H-\frac{z}{2}\right)
$$

（13）式の分母分子に乾燥器の横断面皘 $S \mathrm{~m}^{2}$ を挂けれ ば

$$
\begin{aligned}
& \theta_{d}=\frac{\beta \gamma S}{U S} H\left(1-\frac{z}{2 H}\right) \\
& \text { そして } U S=V,\left(\mathrm{~m}^{3} / \mathrm{hr}\right) \\
& \gamma \mathrm{SH}=M(\mathrm{~kg}) \text { であるから } \\
& \theta_{d}=\frac{\beta M}{V}\left(1-\frac{z}{2 H}\right)
\end{aligned}
$$

本実験の場合は Fig. 3 加ら $c_{0}=0.9 \times 10^{-3} \mathrm{~kg} / \mathrm{m}^{3}$ (露 点 $\left.-22^{\circ} \mathrm{C}\right)$ とし, $20^{\circ} \mathrm{C}$ における Molecular Sieves $4 \mathrm{~A}$ の Isotherm から $q_{0}=0.17 \mathrm{~kg} / \mathrm{kg}$ とする. 天然がスの $z$ については，U上 $\boldsymbol{z}$ との直線的関係が实験的传めら れているので®)，てれを参考に $U=262 \mathrm{~m} / \mathrm{hr}$ において $z=12 \mathrm{~m}$ と㧍く. $M, V, H$ はそれぞれ Table 1 亿与えら れているから，てれらの值を用いて（15）式を計算すれ ば,

$$
\theta_{d}=117 \mathrm{hrs} \cdots
$$

天然ガスより炭酸ガスのほうが transfer zone length が 長い之考えられるので，いま $z=0.14 \mathrm{~m}$ を採用すると

$$
\theta_{d}=108 \mathrm{hrs} \text {............. }
$$

これらの計算結果の $\theta_{d}$ と Fig. 3 の実験結果の破過 時間を比較すれば，扔㧍むね一致している．したがって 中性ガスの吸着帯の巾 $\boldsymbol{z}$ に近い值を用いて行なった上記 の計算は妥当に思われる.

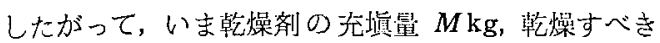
ガスの流量 $V \mathrm{~m}^{3} / \mathrm{hr}$ および入口濃度 $c_{0}$ が既知亡すれ ば，(15)式に $\beta=\frac{q_{0}}{c_{0}}$ を代入して，

$$
\begin{aligned}
& \theta_{d}=\frac{M q_{0}}{V c_{0}}\left(1-\frac{z}{2 H}\right) \\
& H=\frac{M}{\gamma S}, z=\text { const. } \times U \text { であるから }
\end{aligned}
$$

$$
\begin{aligned}
\theta_{d} & =\frac{M q_{0}}{V c_{0}}\left\{1-\frac{\text { const. } \times U}{2 \times \frac{M}{\gamma S}}\right\} \\
& =\frac{M q_{0}}{V c_{0}}\left\{1-\frac{\text { const. } \times V \gamma}{2 M}\right\}
\end{aligned}
$$

$U$ と $z$ との関係加ら

$$
\text { const. }=\frac{z}{U}=\frac{0.12}{262}=0.46 \times 10^{-3} \mathrm{hr}
$$

また文献 8 の值から $\gamma=700 \mathrm{~kg} / \mathrm{m}^{3}$

$$
\text { ゆえに } \theta_{d}=\frac{M q_{0}}{V c_{0}}\left\{1-0.16 \times \frac{V}{M}\right\}
$$

炭酸ガスの場合は transfer zone length が天然ガス の場合より長いと考えられる加ら $U=262 \mathrm{~m} / \mathrm{hr}, z=0.14$ $\mathrm{m}$ と仮定すれば,

$$
\begin{aligned}
& \text { const. }=\frac{z}{U}=\frac{0.14}{262}=0.53 \times 10^{-3} \mathrm{hr} \\
& \text { ゆえに } \theta_{d}=\frac{M q_{0}}{V c_{0}}\left\{1-0.20 \times\left(\frac{V}{M}\right)\right\} .
\end{aligned}
$$

すなわち乾燥すべきガスの湿度従って $c_{0}$ 流量 $V$ お よび $c_{0}$ に平衡な吸着率 $q_{0}$ が与えられれば，(21）式に より乾燥器の Molecular Sieves 充继量 $M$ 之破過時間 $\theta_{d}$ 之の関伱力球められる。

\section{5. 総括}

本研究では实際の溶接に適用される条件で, 結晶ゼオ ライト，活性アルミナ抽よ゙シリカゲルのそれぞれ一定 量が充填された乾燥器について，その乾燥能力を比較し た. そして,

（i）結晶ゼオライトは活性アルミナおよびシリカゲ ルに比べ，きわめて大きな乾燥能力を有することを認め た、すなわち $640 \mathrm{~g}$ の結晶ゼオライトを填めな乾燥器を 用いれば炭酸ボンベ 7 本（炭酸ガス送給時間約 112 時間 ）のガスを通過させ送給してそのガスの露点を $-25^{\circ} \mathrm{C}$ 以下に保持しうる. 特に 5 本までは $-40^{\circ} \mathrm{C}$ 以下を保証 しうる.

（ii）活性アルミナおよびシリカゲルを用いる婸合に は，溥管を脱水ガラスとし，理想的な活性状態すなわち 新しい吸着绪の活性化值後ほど埧燥効果を示さず, 乾燥 能力も $-20^{\circ} \mathrm{C}$ 以下の炭酸ガスをボンベ 2 本まで保䛸し うるに過ぎなかった。 
（iii）破過時間と必要な結晶ゼオライト充填量との関 係について簡単な奏験式を求めた。

本研究の遂行にあたっては，東京大学生産技術研究所 河㴽邦太郎博士抢よび池田憲治氐加ら種々御便宜を与え られ，また専閒的な立場から多くの御教示を忝うした。 結昆ゼオライトも同博士の御好意により入手しえたもの である，両氏に対し樑愿なる謝意を表する。

\section{文献}

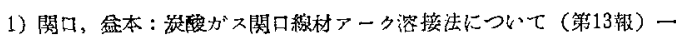

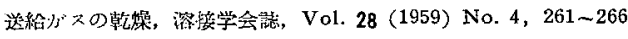

2) Linde: General Information on "Linde" Molecular Sieves
Type $4 \mathrm{~A}$ and $5 \mathrm{~A}$

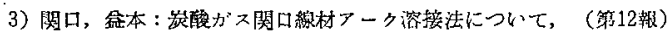

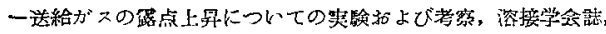
Vol, 28 (1959) No. 2, 112 119

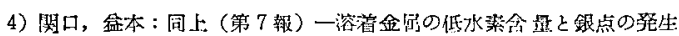
距度, 客接学会誌, Vol, 27 (1958), No. 6, 331 339

5) 河添：吸着塔とえの設計，最近の北学工学 (1950).

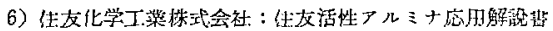

7) 河添：気体拒上行液体の明旁，最近の化学工学 (1956)

8) 河添：吸曾, 新化学工学講座 (1958)

9) R.E. Treybal : Mass Transfer Operations, McGraw-Hill (1955), 497 551

10）河添：未吪表

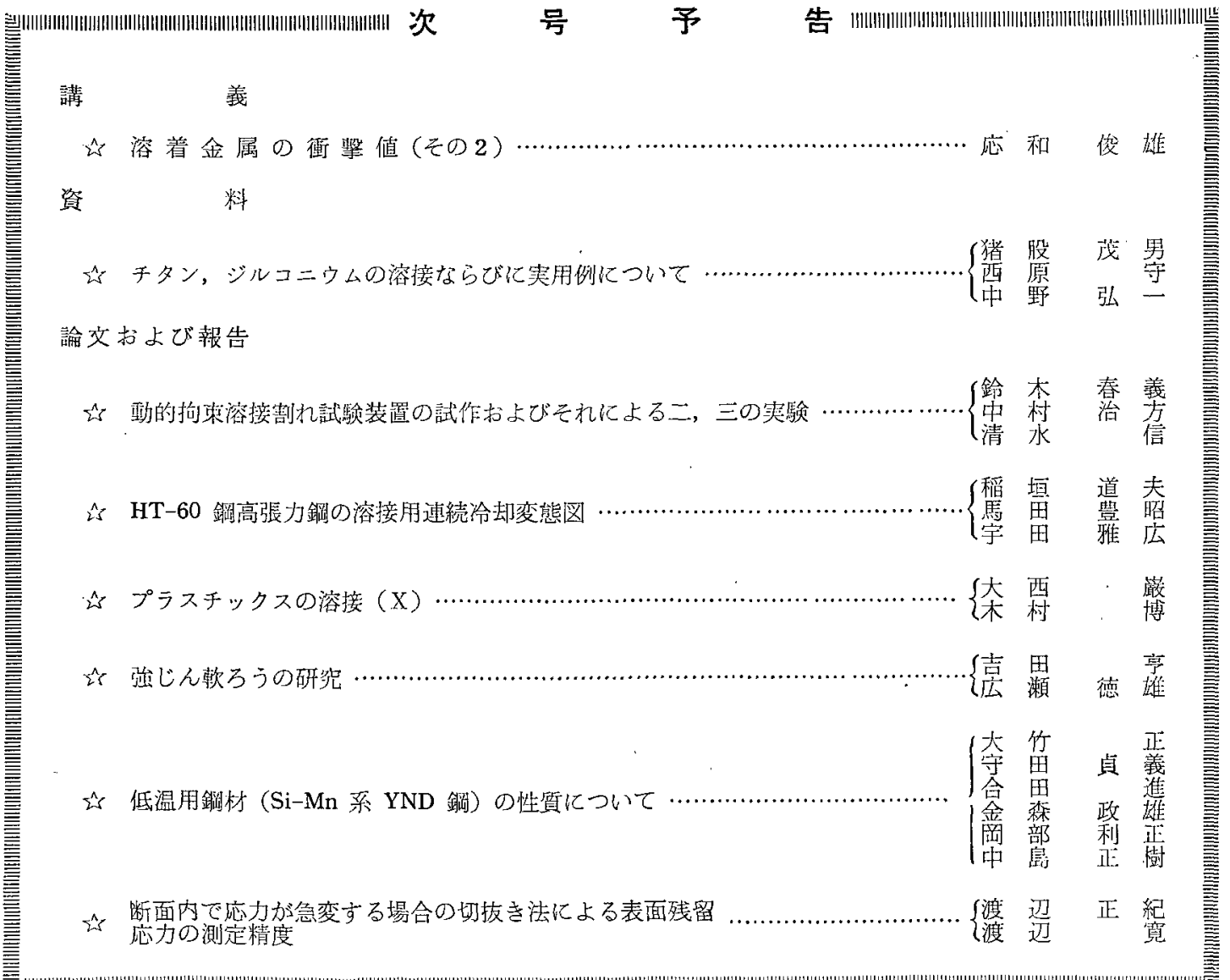

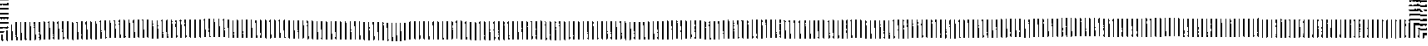

